\title{
SINAIS DE UMA CAMINHADA ECUMÊNICA NO CATOLICISMO
}

\author{
SIGNS OF A WALK IN THE ECUMENICAL CATHOLICISM \\ Vitor Hugo Lourenço*
}

\section{RESUMO}

O ecumenismo é a vocação primeira de todas as igrejas cristãs. Partindo dessa premissa, o presente artigo busca analisar, a partir do catolicismo, os sinais históricos de sua caminhada ecumênica mais recente. Para este propósito, tem-se como ponto de partida o Concílio Vaticano II, de modo particular o seu Decreto Unitatis Redintegratio (UR), visando compreender o que significa o ecumenismo, seus desdobramentos, implicações, avanços e retrocessos. Proporcionando um tempo de esperança e abertura na vida da Igreja Católica, o pontificado de Francisco tem se mostrado sensível ao diálogo ecumênico, mostrando e recuperando sinais de que o diálogo e o movimento ecumênico encontram novamente no catolicismo um solo fecundo para crescer e lançar novas sementes.

Palavras-chave: Ecumenismo. Vaticano II. Caminhada. Sinais. Abertura. Papa Francisco.

\section{ABSTRACT}

Ecumenism is the first vocation of all Christian churches. From this premise, this paper analyzes, from Catholicism, the historical signs of his latest ecumenical journey. For this purpose, it has as its starting point the Second Vatican Council, particularly its Unitatis Redintegratio (UR), to understand what it means ecumenism, its consequences, implications, advances and setbacks. Providing a time of hope and openness in the life of the Catholic Church's pontificate Francisco has proven sensitive to ecumenical dialogue, showing and recovering signs that the dialogue and the ecumenical movement are again in Catholicism a fertile soil to grow and launch new seeds.

Keywords: Ecumenism. Vatican II. Walking. Signals. Opening. Pope Francis.

* Sacerdote católico e religioso passionista. Mestre e doutorando em Teologia pela Pontifícia Universidade Católica do Paraná (PUCPR). Linha de pesquisa: Teologia e Evangelização - Teologia Pastoral. Graduado em Filosofia e Teologia. Especialista em Missiologia e Formação Humana.

\begin{tabular}{|l|l|l|l|l|l|}
\hline Teocomunicação & Porto Alegre & v. 46 & n. 1 & p. $87-103$ & jan.-jun. 2016 \\
\hline
\end{tabular}




\section{Introdução}

No bojo das principais discussões teológicas, encontramos o ecumenismo. Com a proposta de refletir sobre a unidade dos cristãos, o diálogo ecumênico durante um longo período da história não foi bem visto por setores mais conservadores do catolicismo, que rotulavam os praticantes das demais confissões religiosas como "inimigos" ou "hereges". Graças ao advento do Concílio Vaticano II, a Igreja Católica redescobriu a base e o fundamento do ecumenismo presente na Igreja Primitiva e na própria pessoa de Jesus e, abrindo-se ao diálogo com todos aqueles que confessam a mesma fé, se colocando consequentemente de modo significativo no movimento ecumênico e se aproximando das igrejas cristãs. No momento pós-conciliar, vimos parte de todo esforço em direção ao ecumenismo se enfraquecer frente a novos interesses e projetos eclesiais, que foram surgindo ao largo do caminho como, por exemplo, o processo de romanização iniciado no pontificado de João Paulo II, que se refletiria em um novo fechamento eclesial e teológico. A renúncia de Bento XVI e a eleição de Francisco representaram uma volta aos sonhos, projetos e intuições conciliares, permitindo acreditarmos uma vez mais no caminho ecumênico, que estava um tanto sufocado por uma eclesiologia autorreferencial ${ }^{1}$.

Em um contexto marcado por avanços e retrocessos, no que tange especialmente ao ecumenismo, é que se insere a proposta deste artigo. Lançando um olhar sobre o Concílio Vaticano II, especialmente sobre o Decreto Unitatis Redintegratio (UR), nosso objetivo é analisar quais foram as suas principais contribuições, luzes para o tema, percebendo como o diálogo ecumênico foi acolhido no momento pós-conciliar, no que se referem aos seus desdobramentos, conquistas e aplicabilidade. Naturalmente, não temos a pretensão de esgotar a temática, mas lançar uma vez mais o nosso olhar sobre ela, de modo especial neste tempo de pontificado de Francisco, que tem por meio de seus gestos, atitudes e palavras, apontado para o desejo e a necessidade da Igreja redescobrir sua vocação ecumênica, a importância do outro, das culturas e de suas expressões religiosas, em atitude de escuta, respeito e diálogo.

1 BERKENBROCK, V. J. Renovando o sonho ecumênico. p. 183. 


\section{Resquícios da cristandade}

Ao refletirmos sobre a história da Igreja Católica ao longo dos séculos, podemos analisar que o ecumenismo e o diálogo inter-religioso foram vistos como temas espinhosos, retirados das principais pautas de discussão do catolicismo, pouco incentivados para o estudo, causando até mesmo incompreensão e perseguição daqueles que desejavam aprofundá-los, ou criar uma nova consciência sobre a ecumenicidade da fé, da Igreja e acima de tudo da proposta do Reino de Deus, iniciado por Jesus Cristo, presente nos Evangelhos.

Imbuída de uma visão exclusivista da salvação, estandarte de toda a cristandade, a Igreja Católica durante muito tempo condenou aqueles que não faziam parte de suas fileiras, via nas demais confissões religiosas apenas erros e heresias, inimigos que precisavam ser "combatidos", pois não possuíam um magistério confiável, o depósito autêntico da fé, criando uma verdadeira muralha, um abismo, que impedia qualquer tipo de aproximação, tentativa de diálogo, de estabelecimento de partilhas, atividades em conjunto, uma comunhão e uma "cultura" ecumênica de fato $^{2}$.

Tamanho era o fechamento por parte de algumas alas do catolicismo, que o movimento ecumênico, entre outros aspectos, encontrou espaço para o seu florescimento primeiramente no universo protestante no final do século XIX e início do século XX. Segundo Elias, o movimento ecumênico, que chegou a ser proibido pela cúria romana, foi dando seus primeiros passos no catolicismo ainda no século XIX, a partir da iniciativa de teólogos, como Johann Adam Möhler (1796-1838) e John Herny Newmann (1801-1890), que "podem ser considerados precursores e pioneiros do ecumenismo da Igreja Católica", ao proporem uma concepção de unidade eclesial, que superasse uma perspectiva apenas voltada ao institucional, enclausurada em uma espécie da burocracia, sustentando ainda uma eclesiologia, um pensar eclesial, pastoral e teológico, frutos de uma compreensão de Igreja vista como "sociedade perfeita"'.

Um dado bastante significativo em relação ao florescimento de uma consciência ecumênica, por parte da Igreja Católica, foi à acolhida da Semana de Oração pela Unidade dos Cristãos, um marco que até o

WOLFF, E. Caminhos do ecumenismo no Brasil, p. 156.

3 Idem. O ensino ecumênico do Concílio Vaticano II, p. 210. 
momento representa um esforço mútuo de oração, diálogo e reflexão sobre a fé e vida como um todo. Dois elementos ainda são significativos neste caminhar, o primeiro é o reconhecimento do diálogo católicoanglicano (Conversações Malinas) e o segundo, todo esforço realizado pelo teólogo dominicano Yvis Congar, que para muitos foi considerado o primeiro teólogo católico a sistematizar uma eclesiologia em perspectiva ecumênica.

Todas essas iniciativas, entre outras não citadas, foram extremamente importantes em direção a uma mentalidade ecumênica. Contudo, para Elias, nenhuma delas se igualou ao que aconteceu no Concílio Vaticano II. Em suas palavras: "esse Concílio não apenas reconheceu o valor do movimento ecumênico, mas o acolheu como algo próprio da Igreja Católica, integrando-o definitivamente nas iniciativas de diálogo em busca da unidade dos cristãos". Enfatiza, "para isso, o próprio Concílio foi um "fato ecumênico"'4.

\section{Um tempo de renovação}

O Concílio Vaticano II (1962-1965) desde a sua convocação, realização e desdobramentos se mostrou profundamente ecumênico. Com as palavras: "Alegra-se a santa mãe Igreja, porque, por singular dom da Providência divina, amanheceu o dia tão ansioso esperado em que solenemente se inaugura o Concílio Ecumênico Vaticano II...". João XXIII em seu discurso de abertura inaugurava um novo tempo na vida da Igreja, um novo momento marcado agora pela abertura ao diálogo com o mundo moderno, com as ciências, especialmente com as demais igrejas cristãs e confissões religiosas, fomentando e favorecendo o ecumenismo, até então pouco reconhecido e valorizado. Insiste ainda João XXIII: "a Igreja Católica julga, portanto, dever seu empenhar-se ativamente para que se realize o grande mistério daquela unidade, que Jesus Cristo pediu com oração ardente ao Pai celeste, pouco antes do seu sacrifício" (cf. Discurso de Abertura).

Para o papa conciliar, a Igreja tem por missão "promover a unidade na família cristã e humana", frente a uma visível falta de unidade entre os cristãos. Como frutos de todo empenho em vista da unidade, para o pontífice, deve haver a "unidade dos católicos entre si", a "unidade de orações e desejos ardentes", que ainda estão distantes e, por fim, "a

4 WOLFF, E. O ensino ecumênico do Concílio Vaticano II, p. 211. 
unidade na estima e no respeito para com a Igreja Católica, por parte daqueles que seguem as religiões não-cristãs" (cf. Discurso de Abertura).

De modo profético, e podemos dizer também poético, João XXIII dizia que o Concílio por ele inaugurado surgira na Igreja como "dia que promete a luz mais brilhante", enfatizava: "estamos apenas na aurora; mas já o primeiro anúncio do dia que nasce de quanta suavidade não enche o nosso coração!" Conclui: "Aqui tudo respira santidade, tudo leva a exultar! Contemplemos as estrelas, que aumentam com seu brilho a majestade deste templo; aquelas estrelas, segundo o testemunho do Apóstolo são João $(A p 1,20)$, sois vós mesmos; e convosco vermos brilhar aqueles candelabros dourados à volta do sepulcro do Príncipe dos Apóstolos, isto é, as igrejas a vós confiadas $(A p 1,20)$ " (cf. Discurso de abertura).

Pensar sobre o ecumenismo na Igreja Católica, implica refletir sobre as palavras e os gestos de João XXIII. Implica pensar sobre a autoconsciência dessa Igreja a partir do impulso conciliar. Primeiro, porque ele propôs uma renovação ao catolicismo, em sua teologia, suas estruturas, em sua ação pastoral. Segundo, porque nessa renovação é que o ecumenismo tem lugar, seja como causa, seja como consequência da renovação. Prossegue Wolff:

O Concílio foi um ato ecumênico em si mesmo e não é possível compreendê-lo sem considerar esse fato. E o ecumenismo, a partir do Concílio, tornou-se uma forte expressão do ser e do agir de muitos cristãos católicos. Existe uma intrínseca relação entre Concílio Vaticano II e ecumenismo, o que permite afirmar que somente onde o Concílio foi assumido de modo efetivo é que o ecumenismo ganhou espaço no jeito de a Igreja católica ser e agir. Ali, houve abertura para o diálogo com as diferentes tradições eclesiais, religiosas e culturais, tanto no âmbito local quanto no âmbito universal ${ }^{5}$.

O Concílio Vaticano II, convocado justamente no final da Semana de Oração pela Unidade dos Cristãos, contando com a "participação de observadores de diferentes tradições cristãs", nasce com o desejo de reforçar e confirmar a ecumenicidade de Igreja e um caminho de diálogo, que já não pode mais retroceder. $\mathrm{O}$ evento conciliar traz em si uma intenção ecumênica: "ajudar a Igreja a compreender a sua

5 WOLFF, E. O ecumenismo no horizonte do Concílio Vaticano II, p. 404. 
natureza e vocação, identidade e missão, em relação às demais igrejas. A promulgação de um decreto, de um documento oficial, se torna "a maior expressão da convicção ecumênica do Concilio e da integração definitiva da Igreja Católica no movimento ecumênico"6.

\section{Um Decreto que abriu novos horizontes}

O Concílio Vaticano II produziu textos preciosos e primorosos em vista de uma renovação eclesial, de uma volta profunda às fontes bíblicas e patrísticas, e de um desejo de colocar a Igreja em diálogo com o mundo, com as ciências, com a modernidade de um modo geral, perscrutando assim, os "sinais dos tempos", os apelos de tantos "crucificados" do tempo presente, que esperam novas respostas às novas perguntas.

Nesta perspectiva de renovação e busca de colocar-se na "ordem do dia", de "aggiornamento", o Decreto Unitatis Redintegratio (UR), promulgado pela Igreja Católica a partir das reflexões e decisões conciliares, se tornou uma das maiores expressões no que se refere ao ecumenismo e a seus desdobramentos. No bojo de suas afirmações, o que nos chama atenção é a declaração de que a busca de promover "a restauração da unidade entre todos os cristãos" foi um dos principais "propósitos do Sagrado Concílio Ecumênico Vaticano II" (UR 1).

Levando em consideração de que é Deus quem suscita essa unidade, o Concílio nos ensina que o movimento ecumênico só pode ser compreendido como um impulso e uma obra do Espírito Santo, que despertou os cristãos no mundo inteiro e em todas as tradições eclesiais, "tornando-os conscientes do escândalo da divisão e desejosos da unidade" (UR 1-4).

Afirma o Decreto: "este sagrado Concílio, portanto, exorta todos os fieis a que, reconhecendo os sinais dos tempos, solicitamente participem do trabalho ecumênico, favoreçam o diálogo, a comunhão, a unidade" (UR 4). Destacando a importância de um constante processo de renovação, como parte fundamental para a criação de uma mentalidade ecumênica, frisa o texto: "Como toda a renovação da Igreja consiste essencialmente na maior fidelidade à própria vocação, ela é, sem dúvida, a razão do movimento para a unidade. A igreja peregrina é chamada por Cristo a essa reforma perene, que ela própria, como instituição humana e terrena, necessita perpetuamente" (UR 6).

6 WOLFF, E. O ensino ecumênico do Concílio Vaticano II, p. 216. 
Tomando como referência o pressuposto de uma constante e permanente necessidade de mudança e reforma, por parte da Igreja, e também por parte dos cristãos, no que tange a sua mentalidade, atitudes e práticas, para os padres conciliares não há verdadeiro ecumenismo sem "conversão interior", sem um processo de amadurecimento da fé e de nossa consciência cristã. Destaca o texto: "É que os anseios de unidade nascem e amadurecem a partir da renovação da mente, da abnegação de si mesmo e da libérrima efusão da caridade" (UR 7). Conclui o Decreto: "A conversão" é vista neste contexto "como alma do movimento ecumênico" (UR 8). Em vista deste ideal, é preciso favorecer uma "formação ecumênica" a partir dos estudos e dos trabalhos, especialmente para aqueles que "desempenham ministérios" (UR 10).

É neste sentido, como advoga Volney, para o teólogo é por meio deste Decreto que o catolicismo não apenas mostra-se a favor do ecumenismo, como também dá a conhecer a toda sociedade a sua compreensão a respeito, destacando, como temos discutido até então, para além da dimensão institucional, a importância de fato de uma necessidade da conversão, mais precisamente em convergência com o texto, uma "conversão do coração" (UR 7)7.

O Decreto estabelece as bases doutrinais e orientações pastorais para o ecumenismo na Igreja Católica Romana e apresenta-se em três capítulos: a) "Princípios católicos do ecumenismo", tratando da teologia e reconhecendo o Movimento ecumênico como fruto da graça do Espírito Santo (UR 2-4); b) "A prática do ecumenismo" (UR 5-12), dando força, sobretudo ao ecumenismo espiritual (UR 8-9) e à cooperação (UR 12); c) "As Igrejas e Comunidades Eclesiais separadas da Sé Apostólica Romana", buscando maior compreensão e relacionamento entre os cristãos, estabelecendo considerações diferentes entre as Igrejas do Oriente (UR 14-18) e as do Ocidente (UR 19-23) ${ }^{8}$.

Entre outros elementos podemos dizer que os esforços e a influência da Secretaria para Unidade dos Cristãos, instituída em 1960 por João XXIII, tiveram um papel fundamental na elaboração e promulgação deste Decreto tão importante e decisivo em prol do florescimento de uma consciência ecumênica no seio do catolicismo. Suas laudas apontam como objetivo inicial ajudar a Igreja Católica a melhor integrar-se nos caminhos do diálogo ecumênico, antes, durante e depois do evento

BERKENBROCK, V. J. Renovando o sonho ecumênico. p. 191.

8 WOLFF, E. O ecumenismo no horizonte do Concílio Vaticano II, p. 411 
conciliar, especialmente no que tange os seus desdobramentos na vida da Igreja e da sociedade? .

\section{Caminhada ecumênica pós-conciliar}

A convocação e a celebração do Concílio Vaticano II trouxeram inúmeros benefícios para a Igreja Católica. Ainda que a totalidade de suas proposições e propostas não tenham sido levadas totalmente a cabo, possibilitou a chegada de "novos ares", realmente um "novo dia", uma "primavera" como anunciava e sonhava João XXIII em seu Discurso de Abertura. A partir deste contexto de renovação e abertura, que embalou o próprio Concílio, vimos o florescimento e afirmação das Conferências Episcopais, de modo especial a Conferência Latino-americana. No Brasil a criação da CNBB, da CRB, do CONIC, entre outros organismos, que deram um novo rosto, articularam a caminhada cristã em nosso país, promovendo cursos, campanhas, gestos em comum, sinais concretos de uma consciência ecumênica.

Ainda que seu pontificado tenha sido marcado por momentos de “introversão eclesial”, João Paulo II demonstrou certa preocupação com o movimento ecumênico e com o ecumenismo propriamente dito. Em sua Encíclica Ut Unum Sint (1995) que versa sobre esta temática, o pontífice reconheceu que era a "primeira vez na história que a ação em prol da unidade dos cristãos assumiu proporções tão amplas e se estendeu a um âmbito tão vasto" (USS 41). O mesmo papa, segundo Elias, reconheceu também como "frutos do diálogo": a fraternidade reencontrada pelo reconhecimento do único Batismo e pela exigência que Deus seja glorificado na sua obra; a solidariedade no serviço à humanidade; convergências na palavra de Deus e no culto divino; o apreço mútuo dos bens nas diferentes tradições eclesiais; o reconhecimento de que "aquilo que une é mais forte do que o que divide" (UUS 20.41-49)10.

Tomando com referência as decisões conciliares, João Paulo II, entendeu que a progressiva comunhão em espírito de contínua reforma e conversão são os traços "mais típicos e mais importantes do ecumenismo". Segundo ele, não podemos esquecer "que o ímpeto ecumênico do Concílio Vaticano II é um dos resultados do grande empenho da Igreja" em voltar às fontes. Dessa forma, faz memória em

\footnotetext{
9 COSTA, F. A nova perspectiva ecumênica do Concílio Vaticano II.

${ }^{10}$ WOLFF, E. O ecumenismo no horizonte do Concílio Vaticano II, p. 416.
} 
sua carta do gesto profético de Paulo VI, que ao terminar a assembleia conciliar consagrou a vocação ecumênica da Igreja ao retomar "o diálogo da caridade com as Igrejas em comunhão com o Patriarca de Constantinopla, realizando com ele aquele gesto concreto e altamente significativo que 'relegou para o esquecimento' - e 'tirou da memória e do meio das Igrejas' - as excomunhões do passado" (USS 17).

Já temos elementos suficientes para dizer que não existem fundamentos sólidos para a divisão entre os cristãos. Os inúmeros subsídios, declarações e diálogos multilaterais forneceram às Comunidades cristãs úteis instrumentos para discernir o que é necessário ao movimento ecumênico e à conversão que este deve sustentar. Segundo a Encíclica, toda a reflexão construída até o momento é importante sob dois aspectos: "mostram os notáveis progressos já alcançados e infundem esperança por constituírem uma base segura para a busca da unidade, que se há de continuar e aprofundar" (UUS 17).

Para Kasper, isto demonstra que toda nossa caminhada em direção ao ecumenismo e a um Movimento ecumênico constituem uma resposta aos "sinais dos tempos", aos novos desafios que se descortinam a todo instante. Em um tempo marcado por inúmeras guerras, que ceifam milhares de vidas, por sistemas totalitários, por incontáveis ditaduras que provocam um número infinito de vítimas inocentes, segundo ele, os cristãos decidiram "lutar contra as suas antigas divisões, demonstrando que é possível reconciliar-se, não obstante as culpas cometidas por todos no passado. Podemos dizê-lo sem qualquer hesitação: no século passado, o ecumenismo foi um farol que iluminou as trevas e um vigoroso movimento em prol da paz"11.

Como o Papa João Paulo sublinhou muito bem, no século XX houve mártires em todas as Igrejas e em todas as Comunidades eclesiais, pessoas que, animadas por uma profunda consciência cristã, se opuseram a regimes desumanos desprovidos de Deus, comprometendo-se até o fundo pela unidade dos cristãos, pela reconciliação e pela paz. Com a generosa oferta da sua vida pelo Reino de Deus, estes nossos irmãos e irmãs "são a prova mais significativa de que todo o elemento de divisão pode ser vencido e superado com o dom total de si próprio à causa do Evangelho" (UUS 1, LG 15).

Destaca o Cardeal, ecumenismo e missão são, por assim dizer, irmãos. Ambos dão um testemunho clarividente da nossa autocom-

${ }^{11}$ KASPER, W. Reflexões do Cardeal Walter Kasper: caminho e significado do Movimento Ecumênico. 
preensão eclesial: a Igreja nunca é "autossuficiente", mas deve sempre olhar para fora e para além de si mesma. No ecumenismo, o desafio da Igreja consiste em tornar-se cada vez mais consciente do escândalo da divisão, que se tornou particularmente evidente devido à existência de outras Igrejas e Comunidades eclesiais, com a finalidade de chegar a uma reconciliação. Conclui o teólogo: no âmbito da missão, "a Igreja deve abrir-se ao mundo das nações e das culturas, desejosas de receber o anúncio do Evangelho". "Por conseguinte, o ecumenismo e a missão possuem também uma dimensão escatológica; eles tendem para o shalom escatológico, para aquela paz escatológica universal, anunciada pelos profetas do Antigo Testamento"12.

Em meio ao pontificado de João Paulo II e nessa mesma direção, a Congregação para Doutrina da Fé, vai nos dizer que o mistério cristão supera qualquer tipo de barreira de tempo e de espaço e realiza a unidade da família humana, afirma o texto:

Dos mais diversos lugares e tradições, todos são chamados, em Cristo, a participar na unidade da família dos filhos de Deus [...]. Jesus abate os muros de divisão e realiza a unificação, de um modo original e supremo, por meio da participação no seu mistério. Esta unidade é tão profunda que a Igreja pode dizer com São Paulo: "Já não sois estrangeiros nem hóspedes, mas sois concidadãos dos santos e membros da família de Deus" (Ef 2,19) (DI 23).

Podemos intuir então, que o viver e o pensar de modo ecumênico, levando em conta as proposições e os desdobramentos do Concílio Vaticano, se dão a partir da consciência de que formamos uma única família em Cristo, de que a ação do Espírito atinge não somente a todas as pessoas, mas também a sociedade, a história, os povos, as culturas, as religiões (DI 12). Refletindo ainda sobre o ser missionário da Igreja numa perspectiva mais ecumênica, João Paulo II vai nos dizer que as relações da Igreja com as demais denominações cristãs e religiosas, baseiam-se em um duplo aspecto, primeiro: "respeito pelo homem na sua busca de resposta às questões mais profundas da vida, segundo: respeito pela ação do Espírito nesse mesmo homem" ( $R M 28)$.

Tomando as palavras de Bento XVI, em sua primeira mensagem no final da celebração eucarística com os cardeais eleitores na Capela

${ }^{12}$ KASPER, W. Reflexões do Cardeal Walter Kasper: caminho e significado do Movimento Ecumênico. 
Sistina, "Não bastam às manifestações de bons sentimentos. Fazem falta gestos concretos que penetrem nos espíritos e sacudam as consciências, impulsionando cada um à conversão interior, que é o fundamento de todo progresso no caminho do ecumenismo". Como bem disse o sucessor de João Paulo II e maestro de seu pontificado, o ecumenismo precisa mais do que ser apenas pensado e refletido, ser traduzido em ações concretas, em oração e práticas comuns, movimentos que reforçam laços e favorecem a comunhão entre irmãos e igrejas cristãs.

\section{Esperança que se renova}

O final do pontificado de Bento XVI representou mais do que a renúncia de um papa. Manifestou de modo muito significativo, entre outros elementos, a derrocada de uma compreensão eclesial superada, que já não atendia as expectativas e necessidades da Igreja no tempo presente, especialmente no que tange a capacidade de diálogo com o mundo moderno e o despertar para uma consciência ecumênica.

Ainda que animada pelas proposições e reflexos positivos do Concílio Vaticano II, a Igreja viu sua tão esperada "primavera" tornar-se um longo e profundo "inverno". Aos poucos toda a abertura e renovação iniciadas foram dando lugar a um novo projeto de fechamento eclesial e teológico, de romanização, de auto-referencialidade, que fez com que a Igreja se distanciasse uma vez mais do povo, da sociedade, do ecumenismo e do diálogo inter-religioso ${ }^{13}$.

Com a eleição de Francisco, a Igreja Católica teve a oportunidade de retomar o caminho de abertura, diálogo e reforma propostos ao longo do Concílio e que depois de três décadas foram suplantados por um gradativo processo de involução eclesial ${ }^{14}$. O nome Francisco passou a ser mais que um nome, representou o inicio de um novo projeto de Igreja, uma nova eclesiologia e especialmente uma nova postura frente ao ecumenismo, as demais denominações religiosas, a sociedade, de modo particular seus conflitos, guerras, desigualdades sociais e o desrespeito com o meio-ambiente.

Diante deste novo momento, que gera esperanças, incertezas e a possibilidade de reformas e mudanças, questiona Elias: "frente às novidades que Francisco apresenta até o momento, e às iniciativas

\footnotetext{
${ }^{13}$ Cf. PASSOS, J. D. Papa Francisco: entre a crise o carisma, p. 8-31.

${ }^{14}$ BRIGHENTI, A. Perfil pastoral da Igreja que o papa Francisco sonha, p. 13.
} 
tomadas no governo da Igreja, algumas interrogações emergem com força: terá chegado o momento de verdadeiras e profundas reformas na Igreja Católica? Terá o pontificado de Francisco condições para concretizar na igreja as propostas de reforma do Vaticano II?"15.

Tais perguntas são complexas e desafiadoras. O que podemos dizer é que Francisco assumiu para seu pontificado o desejo de levar a diante as reformas e proposições conciliares e acima de tudo o desejo de reformar as estruturas da Igreja, reconhecendo o valor e a importância da colegialidade, descentralizando algumas decisões de Roma, emancipando as Conferências Episcopais e o seu magistério, levando para a Igreja como um todo as reflexões e experiências colhidas em cada continente como, por exemplo, o Documento de Aparecida, que hoje possui um valor inestimável para toda a Igreja.

\section{De Aparecida para Roma}

Vindo de nosso continente e tendo participado da V Conferência do Episcopado Latino-americano, realizada em Aparecida no ano de 2007, Francisco bebeu daquilo que é o mais importante e significativo de nossa tradição, especialmente no que tange ao ecumenismo e o diálogo interreligioso, tão próprios de nossos povos, enraizados em nossas culturas, terras e nações.

Mergulhados em um contexto social e político marcado pela exploração e pelas desigualdades sociais, Aparecida nos diz o que em Cristo se manifesta como uma constante e permanente novidade de vida e missão em todas as dimensões da existência. Isso requer, segundo o texto, a partir de nossa identidade católica, uma evangelização muito mais missionária, em diálogo com todos os cristãos e a serviço de todos os homens. Do contrário, "o rico tesouro do Continente Americano... seu patrimônio mais valioso: a fé no Deus de amor...", corre o risco de seguir desgastando-se e diluindo-se de maneira crescente em diversos setores da população ( $D A p 13)$.

Segundo a reflexão de nosso Episcopado, o ecumenismo não se justifica por uma exigência simplesmente sociológica, mas evangélica, trinitária e batismal: "expressa à comunhão real, ainda que imperfeita"

\footnotetext{
${ }^{15}$ WOLFF, E. Reformas na igreja: chegou a vez do catolicismo? Uma aproximação dos 50 anos do Vaticano II e os 500 anos da reforma luterana, no contexto do pontificado do papa Francisco, p. 536.
} 
que já existe entre "os que foram regenerados pelo batismo" e o testemunho concreto de fraternidade ( $D A p$ 228). Às vezes esquecemos que a unidade é, antes de tudo, um dom do Espírito Santo, e oramos pouco por essa intenção. Citando o Decreto conciliar sobre o ecumenismo, reforça Aparecida: "Esta conversão do coração e esta santidade de vida, juntamente com as orações particulares e públicas pela unidade dos cristãos, hão de se considerar como a alma de todo o movimento ecumênico e com razão pode chamar-se ecumenismo espiritual" (UR 7, DAp 230).

Depositário de nossa tradição latino-americana, Francisco, em sua Exortação Apostólica Evangelii Gaudium, nos recorda que o compromisso ecumênico corresponde à oração do Senhor Jesus pedindo "que todos sejam um só" (Jo 17,21). Em suas palavras, a credibilidade do anúncio cristão seria muito maior, se os cristãos superassem as suas divisões e a Igreja realizasse "a plenitude da catolicidade que lhe é própria naqueles filhos que, embora incorporados pelo batismo, estão separados da sua plena comunhão". Frisa o pontífice: "devemos sempre lembrar-nos de que somos peregrinos, e peregrinamos juntos. Para isso, devemos abrir o coração ao companheiro de estrada sem medos nem desconfianças e olhar primariamente para o que procuramos: a paz no rosto do único Deus". "O abrir-se ao outro tem algo de artesanal, a paz é artesanal". Jesus disse-nos: "Felizes os pacificadores" (Mt 5, 9). Neste esforço, "mesmo entre nós, cumpre-se a antiga profecia: 'Transformarão as suas espadas em relhas de arado" (Is 2, 4). [...] Sob esta luz, o ecumenismo é uma contribuição para a unidade da família humana. (EG 244, 245).

Frente aos novos desafios que se descortinam e a gravidade do contra-testemunho da divisão entre os cristãos, para Francisco, torna-se urgente a busca de caminhos de unidade. Conclamando os cristãos a serem "fermentos de paz", destacando a beleza "de tantas coisas que nos unem", o Bispo de Roma, afirma que o ecumenismo não trata "apenas de receber informações sobre os outros para os conhecermos melhor, mas de recolher o que o Espírito semeou neles como um dom também para nós". "[...] Através de um intercâmbio de dons, o Espírito pode conduzir-nos cada vez mais para a verdade e o bem" (EG 246).

Na compreensão de Francisco, o ecumenismo e o diálogo interreligioso podem e devem ser pensados até mesmo no que diz respeito ao cuidado de nossa Casa Comum. Afirma: a maior parte dos habitantes do planeta declara-se crente, e isto deveria levar as religiões 
a estabelecerem diálogo entre si, visando o cuidado da natureza, a defesa dos pobres, a construção de uma trama de respeito e de fraternidade (LS 7, 201).

A partir dos sinais apontados por Francisco, podemos dizer que a esperança que brota do coração dos que acreditam no ecumenismo é para aqueles que acreditam também no diálogo das religiões. Logo no inicio de seu pontificado, no encontro com representantes das Igrejas e comunidades eclesiais e de outras religiões, Francisco assinala sua vontade de dar continuidade ao caminho de abertura iniciado pelo Vaticano II. Tanto no campo ecumênico como do diálogo com as outras religiões. Sublinha estar ciente do irrevogável desafio em favor "da promoção de amizade e respeito entre homens mulheres de diferentes tradições religiosas" $"$.

A Evangelii Gaudium chama-nos ao encontro com Cristo, pelo qual experimentaremos o amor de Deus. A sair, impelidos pelo Espírito, ao encontro dos outros, comunicando alegria e fazendo o bem. Ao procurarmos a unidade da família humana e o serviço das pessoas, especialmente das mais frágeis. Se buscarmos o mais importante da nossa fé e nos deixarmos levar pela alegria do Evangelho, encontraremos inspiração e esperança para nossa renovação e frutificação também em perspectiva ecumênica, e, desse modo, no diálogo, poderemos, certamente, servir mais ao amor de Deus ${ }^{17}$.

$\mathrm{O}$ que favorece, e muito, essa perspectiva de abertura dialogal de Francisco é sua presença de "pastor", que fala muito mais forte que a presença de uma Papa "doutor", que se fixa mais no encaminhamento doutrinário e disciplinar... Abertura dialogal e respeito à diferença são traços vivos na dinâmica pastoral de Francisco ${ }^{18}$.

Refletindo sobre o ecumenismo a partir do prisma da unidade, Suess, destaca que essa unidade tão sonhada é a construção de uma ponte sobre conflitos sociais, culturais, econômicos, ambientais e religiosos da humanidade. O Espírito Santo é o arquiteto dessa ponte. Por isso, compreendemos a unidade não como uniformidade, mas como diversidade consentida no Espírito Santo. É o Espírito quem suscita a diversidade e ao mesmo tempo realiza a unidade ${ }^{19}$.

\footnotetext{
${ }^{16}$ WOLFF, E. O ensino ecumênico do Concílio Vaticano II, p. 257.

${ }^{17}$ CARDOSO, M. T. F.Aspectos ecumênicos da Evangelii Gaudium, p. 261.

${ }^{18}$ WOLFF, E. O ensino ecumênico do Concílio Vaticano II, p. 161.

19 SUESS, P. Dicionário da Exortação Evangelii Gaudium, p. 165.
} 


\section{Considerações finais}

Após percorrermos o caminho proposto no início de nosso artigo, podemos dizer que se faz necessário, como tem apontado o Papa Francisco, continuarmos o processo de renovação eclesial iniciado no Concílio Vaticano II, de modo especial a sua vinculação com o ecumenismo. Tivemos a oportunidade de verificar que a abertura e a consciência ecumênica acontecem à medida que vamos nos envolvendo com o movimento ecumênico, redescobrindo a importância do outro, 0 valor de sua vivência religiosa. A busca de conhecimento, a reflexão sobre a natureza ecumênica da fé cristã, a participação e o envolvimento em atividades ecumênicas são fundamentais. Quando nos abrimos ao outro e à sua confissão religiosa, desenvolvemos a sensibilidade de reconhecer que Cristo perpassa a todas as pessoas e expressões religiosas. É preciso fazer chegar ao coração aquilo que muitas vezes temos apenas como ideias e conceitos vazios.

Frente aos desafios sociais e políticos que estamos enfrentando, o contexto de novas perguntas, que pedem novas respostas, o câmbio epocal que estamos vivenciando e verificando exigem dos cristãos uma nova atitude. Não se sustenta mais o escândalo da divisão. É preciso termos frente ao outro uma postura de alteridade, de reconhecimento de sua identidade, de seus dons, de sua tradição religiosa. $\mathrm{O}$ ecumenismo é mais do que uma teoria, o ecumenismo é uma forma de agir, uma atitude que perpassa todo o nosso ser Igreja, aponta para o Reino, pede de nós, de nossa confissão religiosa, uma constante conversão do coração, uma constante reforma, para permanecermos fieis a Cristo (UR 6).

Muitos passos já foram dados, possuímos muitos sinais, muitos frutos já foram produzidos, precisamos assumi-los com coragem e profetismo. É preciso, neste processo, neste constante caminhar, fidelidade ao Evangelho e fidelidade ao ser humano. Nessa jornada rumo a uma consciência ecumênica se fazem necessárias algumas transformações: passarmos da concepção de um ecumenismo institucional a uma ideia de pluralidade eclesial; advogarmos em direção de um ecumenismo que passe pela capacidade de convivência, de tolerância, de respeito; um ecumenismo que pense para além do confessional, mas que compreende o significado do discipulado; um ecumenismo que perpasse o aspecto organizacional e programático e seja, de fato, paradigmático do cotidiano, expressão de vida, existencial. 
Devemos pensar sempre o ecumenismo com algo intrínseco à evangelização, partindo da convicção de que toda evangelização é ecumênica e o anúncio do evangelho seja uma exigência comum. Como nos ensina o Papa Francisco, o ecumenismo deve extrapolar o ambiente eclesial e chegar até as "enfermidades globais" como, por exemplo, o cuidado com a nossa casa comum. O ecumenismo deve promover a unidade dos cristãos entorno de todas as questões ligadas à vida, à fé e à promoção social. Para Elias, há que se enfatizar o seu significado "existencial", de "convivência", "co-responsabilidade", parceria, o que é comum a toda a humanidade. Ecumenismo diz respeito ao próprio mundo como condição para ser/existir e ao modo de ser no mundo. "Amplia-se o horizonte semântico do termo: a "ecumene" abriga todos os seres e todos os credos, alargando a meta da unidade buscada" 20 .

Como continuidade desta reflexão a partir de tudo o que discutimos até o presente momento, há necessidade de elaborarmos uma teologia ecumênica, para não incorrermos no risco de realizarmos um ecumenismo apenas prático, mas que encontre de fato uma profunda sustentação teológica comum para o nosso desejo de unidade. Precisamos ainda pensar quais seriam os mais significativos modelos de unidade, para não pensarmos que o ecumenismo é apenas o desejo de uniformidade, mas, pelo contrário, um desejo de unidade na pluralidade de igrejas cristãs. "Sejamos um para que o mundo creia"! (Jo 17,21). Sinais de uma caminhada ecumênica em curso e que pode ir mais longe ainda.

\section{Referências}

BERKENBROCK, Volney José. Renovando o sonho ecumênico. In: SILVA, José Maria (Org.). Papa Francisco: perspectivas e expectativas de um papado. Vozes: Petrópolis, 2014. p. 182-197.

BRIGHENTI, Agenor. Perfil pastoral da Igreja que o Papa Francisco sonha. In: SILVA, José Maria (Org.). Papa Francisco: perspectivas e expectativas de um papado. Vozes: Petrópolis, 2014. p. 13-25.

CARDOSO, Maria Teresa de Freitas. Aspectos ecumênicos da Evangelii Gaudium. In: AMADO, Joel Portela; FERNANDES, Leonardo Agostini (Org.). Evangelii Gaudium em questão: aspectos bíblicos, teológicos e pastorais. São Paulo: Paulinas/Editora PUCRIO, 2015. p. 251-262.

${ }^{20}$ WOLFF, E. Igrejas e ecumenismo: uma relação identitária, p. 29. 
CONGREGAÇÃO PARA A DOUTRINA DA FÉ. Declaração Dominus Iesus: sobre a Unidade e a Universalidade salvífica de Jesus Cristo e da Igreja. Vaticano: Libreria Editrice Vaticana, 2000.

COSTA, Françoá. A nova perspectiva ecumênica do Concílio Vaticano II. Faculdade Católica de Anápolis, 2013. Disponível em: < http://catolicadeanapolis.edu.br/ revmagistro/wp-content/uploads/2013/05/A-NOVA-PERSPECTIVA-ECUM\%C3\% 8ANICA-DO-CONC\%C3\%8DLIO-VATICANO-II.pdf>. Acesso em: 19 maio 2016.

JOÃO XXIII, Discurso do Papa João XXIII na abertura solene do Concílio, In: COSTA, L. (Org.). Documentos do Concílio Ecumênico Vaticano II. São Paulo: Paulus, 1997.

JOÃO PAULO II. Carta encíclica Ut Unum Sint. Sobre o empenho ecumênico. Vaticano: Libreria Editrice Vaticana, 1995.

KASPER, Walter. Pontifício Conselho para a União dos Cristãos - Semana de Oração pela Unidade dos Cristãos (18 a 25 de janeiro de 2008) - Reflexões do Cardeal Walter Kasper: Caminho e significado do Movimento Ecumênico. Disponível em: <http:// www.vatican.va/roman_curia/pontifical_councils/chrstuni/card-kasper-docs/rc_pc_ chrstuni_doc_20080117_kasper-ecumenismo_po.html>. Acesso em: 19 maio 2016.

PASSOS, João Décio. Papa Francisco: entre a crise o carisma. Revista Eclesiástica Brasileira, Petrópolis, v. 75, n. 297, p. 8-31, mar. 2015.

SUESS, Paulo. Dicionário da Exortação Evangelii Gaudium: 50 palavras-chave para uma leitura pastoral da Exortação Evangelii Gaudium - a alegria do Evangelho. São Paulo: Paulus, 2015.

WOLFF, Elias. Caminhos do ecumenismo no Brasil: História, Teologia, Pastoral. São Paulo: Paulinas, 2002.

. Igrejas e ecumenismo: uma relação identitária. Revista Estudos Teológicos EST, São Leopoldo, v. 45, n. 2, p. 18-30, 2005.

. O ecumenismo no horizonte do Concílio Vaticano II. Revista Atualidade Teológica - Departamento de Teologia PUCRIO, Rio de Janeiro, ano XV, n. 39, p. 403-428, set.-dez. 2011.

. O ensino ecumênico do Concílio Vaticano II. In: BRIGHENTI, A.; ARROYO, F. M. (Org.). O Concílio Vaticano II: batalha perdida ou esperança renovada? São Paulo: Paulinas, 2015.

Reformas na igreja: chegou a vez do catolicismo? Uma aproximação dos 50 anos do Vaticano II e os 500 anos da reforma luterana, no contexto do pontificado do papa Francisco. Revista Horizonte - PUCMinas, Belo Horizonte, v. 12, n. 34, p. 534-567, abr.-jun. 2014. 